Harvard Kennedy School Misinformation Review ${ }^{1}$

March 2022, Volume 3, Issue 2

Creative Commons Attribution 4.0 International (CC BY 4.0)

Reprints and permissions: misinforeview@hks.harvard.edu

DOI: https://doi.org/10.37016/mr-2020-93

Website: misinforeview.hks.harvard.edu

\title{
Ridiculing the "tinfoil hats:" Citizen responses to COVID-19 misinformation in the Danish facemask debate on Twitter
}

We study how citizens engage with misinformation on Twitter in Denmark during the COVID-19 pandemic. We find that misinformation regarding facemasks is not corrected through counterarguments or fact-checking. Instead, many tweets rejecting misinformation use humor to mock misinformation spreaders, whom they pejoratively label wearers of "tinfoil hats." Tweets rejecting misinformation project a superior social position and leave the concerns of misinformation spreaders unaddressed. Our study highlights the role of status in people's engagement with online misinformation.

Authors: Nicklas Johansen (1), Sara Vera Marjanovic (1), Cathrine Valentin Kjaer (1), Rebekah Brita Baglini (2), Rebecca Adler-Nissen (1)

Affiliations: (1) Center for Social Data Science, University of Copenhagen, Denmark, (2) Center for Humanities Computing Aarhus, Aarhus University, Denmark

How to cite: Johansen, N., Marjanovic, V. S., Kjaer, V. C., Baglini, R. B., \& Adler-Nissen, R. (2022). Ridiculing the "tinfoil hats:" Citizen responses to COVID-19 misinformation in the Danish facemask debate on Twitter. Harvard Kennedy School (HKS) Misinformation Review, 3(2).

Received: July $8^{\text {th }}, 2021$. Accepted: January $24^{\text {th }}, 2022$. Published: March $2^{\text {nd }}, 2022$.

\section{Research questions}

- How much COVID-19 misinformation related to the facemask debate can we identify on Danish social media?

- What types of arguments are used to spread and correct misinformation on Twitter? How do these arguments differ in how they engage with the topic?

- What role do humor and irony play in people's engagement with misinformation?

\section{Essay summary}

- We studied the spread and rejection of misinformation on Twitter during the first wave of the coronavirus pandemic in Denmark. As an example, we focused on the local facemask debate.

- Using a mixed-methods design, we collected all Danish-language tweets mentioning "facemask" and COVID-related terms posted from February to November 2020. We manually coded each tweet as either spreading, rejecting, or unrelated to misinformation, and then again for the use

\footnotetext{
${ }^{1}$ A publication of the Shorenstein Center on Media, Politics and Public Policy at Harvard University, John F. Kennedy School of Government.
} 
of humor. Finally, tweets were qualitatively analyzed in terms of themes, style, rhetoric, and addressee.

- Misinformation accounts for a small portion of the overall facemask-related tweets with an almost equal number of misinformation spreaders and rejectors. In the first phase of the pandemic, the number of tweets rejecting misinformation exceeded the number of tweets spreading misinformation; over time, however, tweets spreading misinformation outnumbered those rejecting it.

- While other studies show people spread misinformation to appeal to their own social circles, we found that status concerns also characterize tweets rejecting misinformation. In most cases, tweets rejecting misinformation do not engage with substantive claims, but, instead, stigmatize and ridicule misinformation spreaders.

- Further studies are needed to assess the generalizability of these patterns, but our analysis suggests that future initiatives to limit online misinformation should consider status-seeking dynamics among both misinformation spreaders and rejectors.

\section{Implications}

At the start of the coronavirus pandemic, the World Health Organization warned that an infodemic jeopardized pandemic-quelling efforts and encouraged social media platforms to retaliate against the spread of online misinformation (WHO, 2020). Here, we understand misinformation as verifiably false claims presented as factually true, regardless of the disseminators' cognizance of the falsehood (Allcott \& Gentzkow, 2017). By focusing on misinformation rather than disinformation-false information created for the strategic purpose of deceit (Allcott \& Gentzkow, 2017)-we explored users' interactions with false claims regardless of the motivation behind their spread. We simply investigated whether the tweet text supported or countered a false claim. These false claims were drawn from the largest independent Danish fact-checking institution, TjekDet. We relied on the facemask debate, the misinformation theme identified via TjekDet that engaged most tweets. Additionally, we suspected this debate to be a fertile ground for misinformation due to the Danish authorities' change of stance on facemasks partway through the pandemic (Krakov, 2020; Statsministeriet, 2020b) and the often-misinterpreted inconclusive mask study (see Abbasi, 2020), leaving citizens to navigate through changing and conflicting statements regarding the efficacy of facemasks.

Most studies of misinformation during the pandemic focus on the disseminators (Caldarelli et al., 2021; Cinelli et al., 2020; Gallotti et al., 2020), while few scholars have explored how citizens combat false information online (Abidin, 2020; Micallef et al., 2020; Pulido et al., 2020). We investigated all tweets engaging with misinformation. We found that misinformation-related discussion accounted for just 5.04\% of the Danish Twitter debate on facemasks. Moreover, stigmatizing tweets, either ridiculing or criticizing their opponents, were not only created by people spreading false claims about COVID-19 but also by those rejecting false claims. Our findings stem from a limited Twitter dataset with a narrow focus within the COVID-19 debate in a high trust environment (see Methods section). They may not, therefore, be directly applicable to countries with lower trust, other misinformation topics, or different social media platforms. However, they do suggest an interesting pattern that may have wider implications for our understanding of digital misinformation and the role citizens can be expected to play in quelling it.

Other studies have shown that misinformation is spread by people who are in opposition to the established "system" and seek to defend their social status (Petersen et al., 2020). We found a similar dynamic among tweets rejecting misinformation: they do not correct false information but fortify the poster's status and devalue those who believe in false stories. When tweets reject misinformation, they are, to a large extent, appealing to those already critical of misinformation rather than converting those 
they label as wearers of tinfoil hats ${ }^{2}$ or similar derogatory terms. While misinformation spreaders have previously been painted as the bullies of the internet (Petersen et al., 2020), our study suggests that this also holds true for rejectors. Tweets spreading misinformation stories make consistent arguments (on their own skewed terms), but only $28 \%$ of those rejecting misinformation explicitly address false or misleading claims. Most tweets rejecting misinformation mock, ridicule, or stigmatize those spreading misinformation stories, often through irony or sarcasm. Using ironic or humorous comments to correct misinformation can be counterproductive. For example, Abidin (2020) shows that originally satirical Instagram memes shared by young people evolved into misinformation among the elderly on WhatsApp. Our results suggest that rejection is largely aimed at the rejector's own audience, not the misinformation spreaders. Future initiatives and research on misinformation would benefit from investigating statusseeking attempts to increase the respect one has in the eyes of others as a driver for people fighting online misinformation (Magee \& Galinsky, 2008).

In this study, we identify one key argumentative strategy in tweets rejecting misinformation: stigmatization. Existing literature is inconclusive when it comes to the effects of misinformation correction. Some scholars find that only corrections from public institutions or organizations are effective (Van der Meer \& Jin, 2020; Vraga \& Bonde, 2017), highlighting the importance of the corrector's credibility. Other studies argue that combating online hostility requires the mobilization of a sense of connection and we-feeling (Berinsky, 2017; Hannak et al., 2014; Malhorta, 2020; Margolin et al., 2018; Munger, 2017). This suggests that misinformation correction could only work if those spreading misinformation perceive correction as a peer dialogue. In contrast, other scholars argue that corrections of citizens' false claims by strangers can have a positive effect. This is important as Micallef et al. (2020) show: $96 \%$ of all tweets combating misinformation (and those most retweeted) are effectuated by concerned citizens (not professional fact checkers). Focusing on the arguments presented by the corrector and their group membership, one study finds that effective correction requires a proper explanation for why the claim is false (Nyhan \& Reifler, 2015) and that logic-based arguments correct misinformation better than arguments using humor (Vraga et al., 2019). However, Karlsen et al. (2017) show that neither confirmation nor contradiction appear to effectively change people's attitudes. Online debates, instead, tend to reinforce preexisting beliefs. However, presenting people with two-sided arguments can, in some instances, alter people's attitudes.

While counter-arguments are unlikely to be successful in changing the fundamental attitude of misinformation spreaders, perhaps the criticism and ridiculing of misinformation signals to passive observers that spreading misinformation is unacceptable (for the importance of passive audiences, see Marett \& Joshi, 2009; Schmidt et al., 2021). However, stigmatization could also harden the position of those being stigmatized (Goffman, 1963). If this is the case, the challenge going forward is to explore how citizens can correct misinformation without stigmatizing or ridiculing opponents. Our findings suggest that there is a need for more research focused on understanding which types of arguments, tactics, and issue positions are most likely to create backfire effects when engaging with misinformation (see Bail et al., 2018).

\section{Findings}

Finding 1: Misinformation accounts for a small portion of the overall facemask-related tweets in Denmark during the pandemic; we observed slightly more tweets spreading misinformation than rejecting it.

\footnotetext{
${ }^{2}$ Tinfoil hat is a derogatory term used to refer to people "falling for" conspiracy theories and misinformation.
} 
Out of 9,345 sampled Danish tweets about COVID-19 and facemasks, only 5.04\% (471 tweets and retweets) of the tweets engage with misinformation. A closer investigation of these misinformation-linked tweets shows that slightly more tweets spreading misinformation were created than tweets rejecting misinformation (see Figure 1). As we live-collected the tweets (to collect all misinformation tweets before their potential deletion), we did not capture the full reach of each tweet (i.e., the population that has actually seen the tweet). The raw number of tweets (which includes retweets) shows the relative proportions of tweets spreading and rejecting misinformation and was our first step in mapping the arguments used.

When mapping the arguments over time, we saw an initial jump in facemask-related misinformation tweets in late March 2020 with the onset of the pandemic, where the number of facemask-related tweets was low. We saw an additional spike across all arguments in August just before facemasks became mandatory on public transportation (Statsministeriet, 2020b). While, initially, misinformation rejection anticipated the growth of misinformation, the share of misinformation tweets gradually increased just before the first mandatory facemask requirement and continued to increase every time the government announced new facemask-related regulations (Statsministeriet, n.d.). By October, the number of tweets spreading misinformation exceeded those rejecting it. By December, $2.97 \%$ of all Danish tweets about facemasks in the time period spread misinformation, and only $2.07 \%$ rejected it.

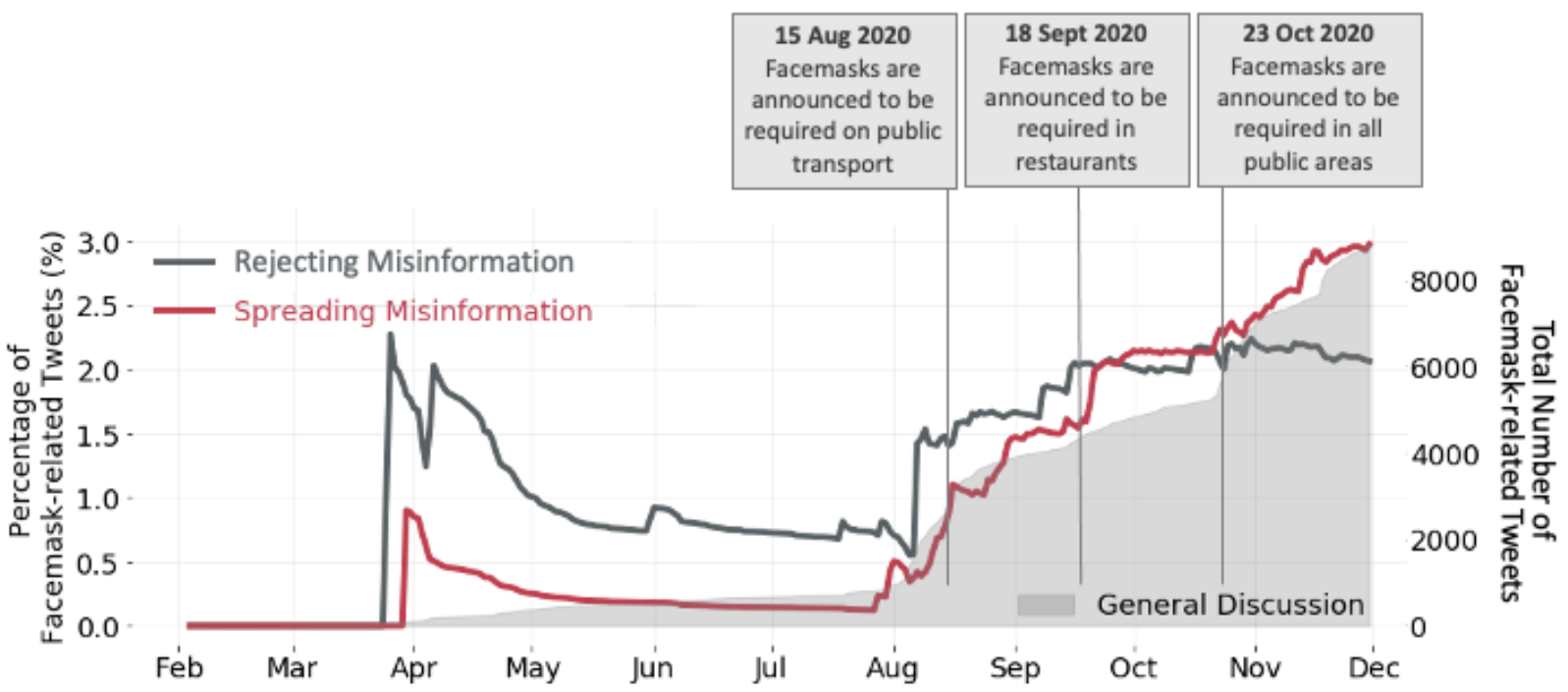

Figure 1. The growth of misinformation-related tweets during 2020. Tweets engaging with misinformation only account for a small portion of facemask-related tweets in Denmark. In the first phase of the pandemic, the number of tweets rejecting misinformation exceeded the number of tweets spreading misinformation; over time, tweets spreading misinformation outnumbered those rejecting it.

Finding 2: There is a near equal number of users spreading and rejecting misinformation, but those spreading misinformation are more active on the topic.

The number of unique users rejecting $(n=161)$ and spreading misinformation $(n=158)$ are almost equal. However, student t-tests show that users spreading misinformation tweet significantly more about facemasks ( $\mu=1.76 \pm 2.24$ tweets) than users rejecting it ( $\mu=1.20 \pm 0.67$ tweets), $t(318)=3.04, p=.003$, $d=0.34)$. The size of this effect is moderate, and we see no difference between the two groups in their overall frequency of posts. In sum, the groups in our dataset resemble each other in size, but the misinformation spreaders tweet more about the subject. 
Finding 3: Tweets rejecting misinformation are three times more likely to use humor than tweets spreading misinformation.

We find that those rejecting misinformation are over three times more likely to use humor (via emoji use, image use, or jokes) (33.2\%) than those spreading misinformation $(8.3 \%), t(469)=7.20, p<.0001, d=$ 0.67). Our coders found that posts using humor were difficult to interpret (they are 14.3 times more likely to be coded as difficult to score, $t(469)=15.07, p<.0001, d=1.62)$; however, there is no significant difference $(p>.01)$ in the scoring difficulty between tweets spreading and rejecting misinformation.

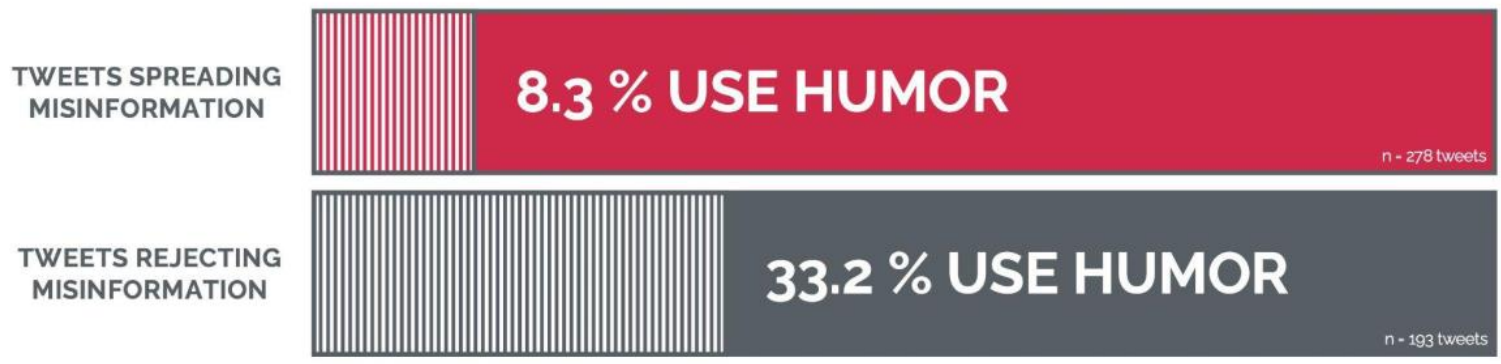

Figure 2. Percentage of humorous tweets across spreaders and rejectors from misinformation. The proportion of tweets using humor is larger among tweets rejecting misinformation, compared to tweets spreading misinformation.

Finding 4: Users spreading misinformation put forward explicit and agitated arguments for why COVID-19 isn't real or, more often, that the use of facemasks is dangerous.

The majority of unique misinformation tweets (non-retweets) warn against using facemasks. As shown in Figure 3, these arguments either claim that facemasks are unnecessary as COVID-19 doesn't exist (39\%) or that using facemasks makes one sick (55\%). Among the latter, many tweets rely on research and technical explanations to prove their point: "Check the documentation! It's harmful to wear facemasks as $\mathrm{CO} 2$ levels rise to toxic levels within seconds of wearing one." A smaller fraction of tweets do not contain concrete arguments against the use of facemasks but instead blame immigrants for improper donning of facemasks (6\%). As shown in Figure 2, only $8.3 \%$ of misinformation tweets use humor to support their arguments, of which some ridicule those following corona guidelines using words such as "lemmings," "fakefluenze," "selfish boomers," and "corona-mafia." However, these ridiculing comments are mainly present in tweets propagating racist arguments or denying the existence of COVID-19. They are rarely present in tweets claiming that facemasks make one sick. Across all arguments, the discussions can become charged and use profanity (e.g., "All the facemask bullshit is just symbolic politics of the worst caliber," "tear off the mouth diaper and burn it") or aggressive punctuation ("when will we drop the need to wear facemasks?!"). Overall, tweets spreading misinformation often have a condescending tone and aim to refute the dominant discourse.

Finding 5: Most tweets rejecting misinformation didn't address the misinformation explicitly; they instead joked to their own followers about people believing in misinformation.

The majority of tweets rejecting misinformation are not aimed at correcting false or misleading claims. As shown in Figure 3, more than half of the tweets rejecting misinformation do not argue explicitly against misinformation; instead, they stigmatize or mock the misinformation spreaders (62\%). Some tweets put forward arguments criticizing misguided newspaper articles (10\%), and only a quarter of the tweets actually counter-argued misinformation claims (28\%). 
Crucially, the majority of tweets rejecting misinformation talked about the misinformation spreaders and not with them. In these tweets, misinformation spreaders were described as "idiots" and "wearers of tinfoil hats" or stigmatized as an "anti-facemask-faction." Most of these tweets solely contained ridiculing comments like this example: "Now, due to coronavirus, we don't just need to wear a facemask outside, but also to walk around carrying our tinfoil hats... \#URL\#." These tweets are not characterized by engaging in debates or putting forward arguments to convince misinformation spreaders of their misguided positions, but rather stigmatizing and ridiculing.

\section{HOW TWEETS ARGUE WHEN ENGAGING WITH MISINFORMATION}

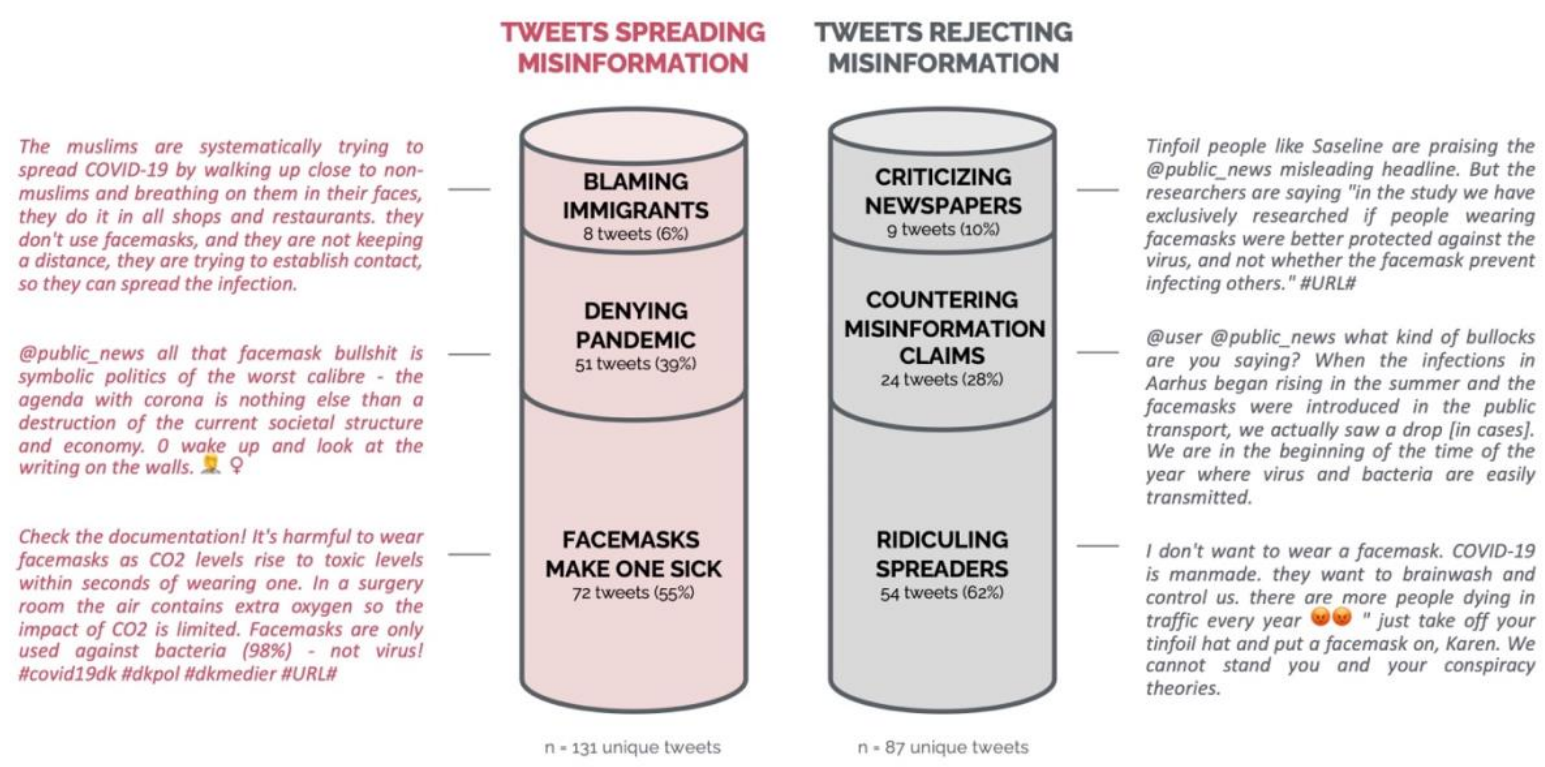

Figure 3. The distribution of arguments across unique tweets spreading and rejecting misinformation. The majority of tweets spreading misinformation explicitly argue against the use of facemask while the majority of tweets rejecting misinformation do not address these substantial concerns; instead, they ridicule the misinformation believers.

\section{Methods}

We studied facemask-related misinformation on Twitter in Denmark. The nature of our single case study limits generalizability (see Appendix A).

\section{Data collection}

Our data was collected between February 1 to November 30, 2020. We primarily live-collected data from Twitter via its API to ensure that we did not underestimate the number of tweets spreading misinformation. In recent years, Twitter has introduced several defense mechanisms to hinder the spread of misinformation by banning or deleting content. Therefore, we live-collected as many tweets as possible and relied only on historical tweets from the Premium Twitter API to fill gaps. 
The live collection of tweets occurred between April 15 to June 23 and April 3 to November, 2020. ${ }^{3}$ These tweets were queried using the most common Scandinavian words from the Opensubtitles word frequency lists (Lison \& Tiedemann, 2016). We removed words non-specific to Scandinavian languages and combined the 100 highest frequency unique words from each language to query live-streamed tweets via the Twitter API using DMI-TCAT (Borra \& Rieder, 2014). Finally, the Twitter native classifier was used to identify Danish tweets.

The Premium Twitter API was used to fill in the remainder of the dataset (February 1 to April 15, 2020; June 23 to August 3, 2020, and October 28, 2020). These tweets were queried using most the frequent Danish words obtained from the Snowball library (Snowball, n.d). We used language as a proxy for a country given the local specificity of the Scandinavian languages.

Our dataset may consist of bots and cyborgs. Although methods have been developed to detect bots (Davis et al., 2016; Wojcik et al., 2018), many are not yet available in the Danish language.

\section{Coding}

To collect misinformation, we identified all Danish tweets containing at least one COVID-related and one facemask-related keyword, ${ }^{4}$ leaving 9,345 tweets (5,712 unique tweets) (see Appendix B).

Six coders were trained on a pre-defined codebook to score each unique tweet as irrelevant, spreading, or rejecting misinformation. Additionally, for each unique tweet, they noted if a) it contained humor and b) it was difficult to code (see Appendix D). The codebook describes every verified Danish misinformation story from the fact-checking site TjekDet.dk (see Appendix C \& D).

Intercoder reliability was calculated on fifty randomly selected tweets from our dataset; the coders scored a Krippendorffs alpha of 0.81 for the codes spreading misinformation, rejecting misinformation, or irrelevant; a value of 0.80 is sufficient to suggest coder agreement (Krippendorff, 2004). Humor annotation had a Krippendorf's alpha of 1.0, suggesting perfect agreement. Finally, we matched the coded unique tweets to the duplicate tweets to determine the total number of tweets spreading and rejecting facemask-related misinformation.

\section{Quantitative and qualitative analysis}

We used Student's t-tests with a p-value threshold of 0.01 -the standard test for significant differences in means of two groups - to compare misinformation spreaders and rejectors. We report our $t$ values with the degrees of freedom alongside the obtained $p$-value, following APA convention. In addition, Cohens $d$ was calculated to determine the effect sizes for each comparison. During our qualitative analysis, each tweet was given only one code category. The six categories were identified through an open coding of a sample of tweets. Based on these categories, we analyzed the full sample of misinformation-related tweets ( $n=218$ unique tweets) (see Appendix E).

\section{Bibliography}

Abbasi, K. (2020). The curious case of the Danish mask study. The BMJ, 371. https://doi.org/10.1136/bmj.m4586

\footnotetext{
${ }^{3}$ The Danish Twitter dataset was collected by Rebekah Brita Baglini and Kristoffer Laigaard Nielbo at the Center for Humanities Computing Aarhus, which is part of Aarhus University, Faculty of Arts.

${ }^{4}$ The Danish word for facemask (mundbind) is unambiguous.
} 
Abidin, C. (2020). Meme factory cultures and content pivoting in Singapore and Malaysia during COVID19. Harvard Kennedy School (HKS) Misinformation Review, 1(3). https://doi.org/10.37016/mr$\underline{2020-031}$

Allcott, H., \& Gentzkow, M. (2017). Social media and fake news in the 2016 election. Journal of Economic Perspectives, 31(2), 211-236. https://doi.org/10.1257/jep.31.2.211

Bail, C. A., Argyle, L. P., Brown, T. W., Bumpus, J. P., Chen, H., Fallin Hunzaker, M. B., Lee, J., Mann, M., Merhout, F., \& Volfovsky, A. (2018). Exposure to opposing views on social media can increase political polarization. Proceedings of the National Academy of Sciences of the United States of America, 115(37), 9216-9221. https://doi.org/10.1073/pnas.1804840115

Berinsky, A. J. (2017). Rumors and health care reform: Experiments in political misinformation. British Journal of Political Science, 47(2), 241-262. https://doi.org/10.1017/S0007123415000186

Borra, E., \& Rieder, B. (2014). Programmed method: Developing a toolset for capturing and analyzing tweets. Aslib Journal of Information Management, 66(3), 262-278. https://doi.org/10.1108/AJIM-09-2013-0094

Caldarelli, G., de Nicola, R., Petrocchi, M., Pratelli, M., \& Saracco, F. (2021). Flow of online misinformation during the peak of the COVID-19 pandemic in Italy. EPJ Data Science, 10(1), 123. https://doi.org/10.1140/EPJDS/S13688-021-00289-4

Chen, E., Lerman, K., \& Ferrara, E. (2020). Tracking social media discourse about the COVID-19 pandemic: Development of a public coronavirus Twitter data set. JMIR Public Health and Surveillance, 6(2), e19273. https://doi.org/10.2196/19273

Cinelli, M., Quattrociocchi, W., Galeazzi, A., Valensise, C. M., Brugnoli, E., Schmidt, A. L., Zola, P., Zollo, F., \& Scala, A. (2020). The COVID-19 social media infodemic. Scientific Reports, 10(1), 16598. https://doi.org/10.1038/s41598-020-73510-5

Dam, P. S. (2019, February 4). Hvem bruger sociale medier? [Who uses social media?]. Berlingske. https://www.berlingske.dk/nyheder/hvem-bruger-sociale-medier

Davis, C. A., Varol, O., Ferrara, E., Flammini, A., \& Menczer, F. (2016). BotOrNot: A system to evaluate social bots. In WWW 16 Companion: Proceedings of the 25th International Conference Companion on World Wide Web (pp. 273-274). International World Wide Web Conferences Committee. https://doi.org/10.1145/2872518.2889302

Gallotti, R., Valle, F., Castaldo, N., Sacco, P., \& De Domenico, M. (2020). Assessing the risks of 'infodemics' in response to COVID-19 epidemics. Nature Human Behaviour, 4(12), 1285-1293. https://doi.org/10.1038/s41562-020-00994-6

Goffman, E. (1963). Stigma: Notes on the management of spoiled identity. Simon and Schuster.

Hannak, A., Margolin, D., Keegan, B., \& Weber, I. (2014). Get back! You dont know me like that: The social mediation of fact checking interventions in Twitter conversations. In Proceedings of the 8th International Conference on Weblogs and Social Media (pp. 187-196). Association for the Advancement of Artificial Intelligence. https://www.aaai.org/ocs/index.php/ICWSM/ICWSM14/paper/view/8115

Illumi. (2021, June 30). 6 populære sociale medier [6 popular social media]. https://www.illumi.dk/viden/de-mest-populaere-sociale-medier/

Karlsen, R., Steen-Johnsen, K., Wollebæk, D., \& Enjolras, B. (2017). Echo chamber and trench warfare dynamics in online debates. European Journal of Communication, 32(3), 257-273. https://doi.org/10.1177/0267323117695734

Krakov, R. (2020, August 15). Sundhedsmyndighedernes vej fra afvisning af mundbind til krav om mundbind [The health authorities way from dismissing to requiring facemasks]. Berlingske. https://www.berlingske.dk/samfund/sundhedsmyndighedernes-vej-fra-afvisning-af-mundbindtil-krav-om-mundbind 
Krippendorff, K. (2004). Reliability in content analysis. Human Communication Research, 30(3), 411-433. https://doi.org/10.1111/j.1468-2958.2004.tb00738.x

Lison, P., \& Tiedemann, J. (2016). OpenSubtitles2016: Extracting large parallel corpora from movie and TV subtitles. In N. Calzolari, K. Choukri, T. Declerck, S. Goggi, M. Grobelnik, B. Maegaard, J. Mariana, H. Mazo, A. Moreno, J. Odijk, \& S. Piperidis (Eds.), Proceedings of the 10th International Conference on Language Resources and Evaluation (pp. 923-929). European Languages Resources Association. http://www.Irecconf.org/proceedings/Irec2016/pdf/947 Paper.pdf

Magee, J. C., \& Galinsky, A. D. (2008). Social hierarchy: The self-reinforcing nature of power and status. Academy of Management Annals, 2(1), 351-398. https://doi.org/10.5465/19416520802211628

Marett, K., \& Joshi, K. D. (2009). The decision to share information and rumors: Examining the role of motivation in an online discussion forum. Communications of the Association for Information Systems, 24(1), 47-68. https://doi.org/10.17705/1CAIS.02404

Malhotra, P. (2020). A relationship-centered and culturally informed approach to studying misinformation on COVID-19. Social Media + Society, 6(3). https://doi.org/10.1177/2056305120948224

Margolin, D. B., Hannak, A., \& Weber, I. (2018). Political fact-checking on Twitter: When do corrections have an effect? Political Communication, 35(2), 196-219. https://doi.org/10.1080/10584609.2017.1334018

Micallef, N., He, B., Kumar, S., Ahama, M., \& Memon, N. (2020). The role of the crowd in countering misinformation: A case study of the COVID-19 infodemic. In Proceedings of the 2020 IEEE International Conference on Big Data (pp. 748-757). IEEE. https://doi.org/10.1109/BigData50022.2020.9377956

Munger, K. (2017). Tweetment effects on the tweeted: Experimentally reducing racist harassment. Political Behavior, 39(3), 629-649. https://doi.org/10.1007/s11109-016-9373-5

Nyhan, B., \& Reifler, J. (2015). The effect of fact-checking on elites: A field experiment on U.S. state legislators. American Journal of Political Science, 59(3), 628-640. https://doi.org/10.1111/ajps.12162

OECD. (2021). Trust in government (indicator). https://doi.org/10.1787/1de9675e-en

Petersen, M. B., Osmundsen, M., \& Arceneaux, K. (2020). The "need for chaos" and motivations to share hostile political rumors. PsyArXiv. https://doi.org/10.31234/osf.io/6m4ts

Pew Research Center. (2018, May 17). Facts on news media \& political polarization in Italy. https://www.pewresearch.org/global/fact-sheet/news-media-and-political-attitudes-in-italy/

Pulido, C. M., Villarejo-Carballido, B., Redondo-Sama, G., \& Gómez, A. (2020). COVID-19 infodemic: More retweets for science-based information on coronavirus than for false information. International Sociology, 35(4), 377-392. https://doi.org/10.1177/0268580920914755

Schmidt, T., Salomon, E., Elsweiler, D., \& Wolff, C. (2021). Information behavior towards false information and "fake news" on Facebook: The influence of gender, user type and trust in social media. In Information Between Data and Knowledge (pp. 125-154). Werner Hülsbusch. https://doi.org/10.5283/epub.44942

Shahi, G. K., Dirkson, A., \& Majchrzak, T. A. (2021). An exploratory study of COVID-19 misinformation on Twitter. Online Social Networks and Media, 22, 100104. https://doi.org/10.1016/j.osnem.2020.100104

Snowball (n.d.). String processing language for creating stemming algorithms. https://snowballstem.org/

Statsministeriet (2020b, August 15). Pressemøde den 15. august 2020 [Press confrence of August 15, 2020]. https://www.stm.dk/presse/pressemoedearkiv/pressemoede-den-15-august-2020/ 
Statsministeriet (n.d.). Pressemødearkiv [Press conference archive]. https://www.stm.dk/presse/pressemoedearkiv

Van der Meer, T. G. L. A., \& Jin, Y. (2020). Seeking formula for misinformation treatment in public health crises: The effects of corrective information type and source. Health Communication, 35(5), 560-575. https://doi.org/10.1080/10410236.2019.1573295

Vosoughi, S., Roy, D., \& Aral, S. (2018). The spread of true and false news online. Science, 359(6380), 1146-1151. https://doi.org/10.1126/science.aap9559

Vraga, E. K., \& Bode, L. (2017). Using expert sources to correct health misinformation in social media. Science Communication, 39(5), 621-645. https://doi.org/10.1177/1075547017731776

Vraga, E. K., Kim, S. C., \& Cook, J. (2019). Testing logic-based and humor-based corrections for science, health, and political misinformation on social media. Journal of Broadcasting \& Electronic Media, 63(3), 393-414. https://doi.org/10.1080/08838151.2019.1653102

Wojcik, S., Messing, S., Smith, A., Rainie, L., \& Hitlin, P. (2018). Bots in the Twittersphere. Pew Research Center. https://www.pewresearch.org/internet/2018/04/09/bots-in-the-twittersphere/

WHO. (2020, February 8). Director-Generals remarks at the media briefing on 2019 novel coronavirus on 8th of February 2020. https://www.who.int/director-general/speeches/detail/director-generals-remarks-at-the-media-briefing-on-2019-novel-coronavirus---8-february-2020 


\section{Acknowledgements}

We wish to thank the editors, the two reviewers, Michael Bang Petersen, Andreas Roepstorff, Sune Lehmann, Frederik Hjorth, Asmus Leth Olsen, Gregory Eady, Amalie Pape, Kristoffer Laigaard Nielbo, Matias Piqueras, SODAS employees and all the members of the HOPE project for helpful comments.

\section{Funding}

Grant CF20-0044, HOPE: How Democracies Cope with Covid-19, from the Carlsberg Foundation funded the study.

\section{Competing interests}

The authors declare no competing interests.

\section{Ethics}

Our research complies with University of Copenhagen's Code of Conduct for Responsible Research.

\section{Copyright}

This is an open access article distributed under the terms of the Creative Commons Attribution License, which permits unrestricted use, distribution, and reproduction in any medium, provided that the original author and source are properly credited.

\section{Data availability}

All materials needed to replicate this study are available via the Harvard Dataverse: https://doi.org/10.7910/DVN/KIUWDB 


\section{Appendix A: Supplemental methods information}

\section{The Danish facemask debate}

We studied facemask-related misinformation in Denmark, a country with high trust in the government (OECD, 2021; Shahi et al., 2021) and the media (Pew, 2018), during the first wave of the pandemic (February - November 2020) and before the second lockdown in December 2020. Given the nature of our single case study, we cannot necessarily expect similar results in countries with lower trust, other misinformation topics, or different social media platforms.

We focused on facemask-related misinformation, given its importance in the Danish COVID-19 debate. This was the largest misinformation theme of those we identified (see below). We identified 8,330 unique tweets containing both a COVID-19-related and misinformation-related keyword, of which $68.6 \%$ related to the facemask theme. While this does not necessarily mean that there was more misinformation on facemasks compared to other themes (e.g., vaccines), it suggests greater Twitter engagement within this particular period.

\section{Twitter}

Our study uses Twitter data, following other papers studying misinformation (Chen et al., 2020; Gallotti et al., 2020; Shahi et al., 2021; Vosoughi et al., 2018). On Twitter, users can interact without mutual connection, enabling us to study the dynamics of misinformation on a platform where users engage outside their usual social network. Additionally, Twitter data is easily accessible. In Denmark, Twitter is a politically important platform attracting traditional media, politicians, and opinion-makers (Illumi, 2021), although only $7 \%$ of the Danish population actively use Twitter (Dam, 2019). Danish men are nearly three times more prone to use Twitter once a week than women, and it is most popular with middle-aged users (34\% of those between 30-49 use Twitter) and those between $15-17$ years (20\%), though not with those over 60 (2\%) (Dam, 2019). While our findings may not be directly applicable to other social media platforms (e.g., Facebook), they provide unique insights into the dynamics between users engaging with misinformation. 


\section{Appendix B: Tweet isolation and annotation details}

COVID-related key terms:

- covid

- corona

- epidemi

- virus

- smitte

- pandemi

- karantæne

- krise

- udbrud

- lockdown

- lukket ned

- nedlukning

- afstand

- bliv hjemme

Facemask-related key terms:

- mundbind

- mb

- mundble

- faceble 


\section{Appendix C: Guidelines for selecting misinformation stories from TjekDet}

TjekDet provides the most extensive and complete overview of verified false stories within Denmark. It is the largest independent Danish fact-checking site and the only Danish representative in the international fact-checking alliance Poynter.org and Googles Fact Check Tools. TjekDet verifies both misinformation stories specific to Denmark and stories originating outside of Denmark but still disseminated within Denmark.

- We only included fact-checks and not articles discussing misinformation or describing other types of online scams from TjekDet.dk.

- We only excluded fact-check articles where the verdict is true. All other misinformation stories are included in our collection.

- To make sure our collection only included COVID-19 related stories, we excluded stories that did not mention the virus in some way.

- We excluded all stories where the verdicts were time-dependent (for example, classifying any claim about the infection rate is dependent on the point in time the claim is made and examined). These time-sensitive stories were excluded to ease the annotation process. We measured misinformation over time, and, as these claims can be false at one point in time and true at a later point, they make misinformation difficult to code after a time delay.

- Regarding facemasks, we kept all the stories claiming that wearing facemasks have health consequences. However, we excluded all stories debating whether facemasks are a good strategy to prevent corona. This is because the verdicts of these claims vary over time in Denmark, as the health authorities changed their recommendations over time.

- We excluded fact-checks that did not focus on a specific claim (these instead often tried to clarify contradictory statements).

- Stories were provided as examples of misinformation but were not expected to show the full extent of all misinformation stories. Coders were allowed to mark a previously unseen story as misinformation. To do so, coders were pointed to reliable health sources. 


\section{Appendix D: Codebook}

Explanation in English: This appendix includes the original codebook (in Danish), which was given to the coders. In this section, we provide a brief summary of the process and our categories.

The codebook was compiled on March 11, 2021, and contains the guidelines and process for annotation, a description of the different codes (spreading and rejecting misinformation, irrelevant, etc.), and an appendix with examples of information and misinformation. The codebook covered all verified facemask-related misinformation stories on TjekDet from January to November 2020. For reliable information, we relied on the Danish Health Authority's webpage on facemasks.

\section{The process}

Each coder was asked to label each tweet into one of the following three categories: spreading misinformation, rejecting misinformation, or irrelevant. Coders could place each tweet into only one category, but all tweets had to be labeled. Additionally, they were asked to indicate: a) whether the tweet was difficult to code on a binary scale of 1 or 0 , where 1 indicated that the tweet was difficult and 0 indicated that it was not; and b) whether the tweet used humor on a binary scale of 1 or 0 , where 1 indicated that the tweet used humor and 0 indicated that it did not.

Coders used the codebook to decide which tweets should be labeled as spreading misinformation, rejecting misinformation, or irrelevant. Using test data, we did two rounds of training sessions with the coders before the actual coding process. During the test rounds, we went through all annotations together and discussed all cases of doubt or uncertainty and updated the codebook accordingly.

The categories

Section 4 of the codebook includes a description of each category, including examples of tweets in each category.

- Spreading misinformation: All tweets expressing false claims as if they were true. The decisive factor is if the tweet appears in agreement with the false claim. Tweets spreading misinformation about facemasks will, for example, have claims that facemasks are harmful to one's health, including claims that facemask increases the risk of getting infected with the coronavirus.

- Rejecting misinformation: This category comprises all tweets that ridicule misinformation or people believing in misinformation, counter-argue false claims, or distance themselves from a false claim explicitly or implicitly.

- Irrelevant: This category comprises all tweets mentioning facemasks, but without relating it to a false claim (either by spreading or rejecting it).

- Humor: All tweets that use humor. This includes tweets that use humor as a way to ridicule or mock, as well as tweets that use irony or sarcasm. Be especially aware of the use of emojis

- Difficult: All tweets that are difficult to code. 


\section{Codebook}

\section{Introduktion}

HOPE er et forskningsprojekt forankret på KU, DTU \& AU. Vi fors $\varnothing$ ger vi at forstå adfærden blandt demokratier og borgere under corona pandemien. Læs mere: https://hope-project.dk/.

I dette specifikke projekt undersøger vi hvor meget covid-19 misinformation der er på Twitter i en dansk kontekst. Vi har siden begyndelse af epidemien indsamlet 90 millioner danske tweets som vi vil benytte som datagrundlag for unders $\varnothing$ gelsen. Vi læner os op af fact-checking sider for at afg $\varnothing$ re om en en påstand er sand eller falsk og har således identificeret omkring 50.000 tweets som mennesker nu skal læse og derefter give et tag/kode (annotere). En kode kan for eksempel være at tweetet aktivt spreder misinformation eller gør grin med/håner misinformation.

I de følgende afsnit vil du kunne læse om

- Hvilke dokumenter vi ønsker at du læser før du begynder at annotere

- Hvilket ark du skal benytte til at annotere tweets

- Hvordan vi ønsker at du skal annotere tweets

Du er velkommen til at sende os spørgsmål på mail. Vi samler sammen løbende. Hvis dit spørgsmål er relevant for andre vil spørgsmål + svar blive udsendt på mail. Alternativt tages det i plenum på af vores kommende zoom møder.

Name

Titel

Email

Name

Titel

Email

Name

Titel

Email

Name

Titel

Email

Før du går videre, bedes du gå ind på nedenstående link for at se vores bilag. Her kan du læse om de overordnede grupper (temaer), som vi har valgt at dele tweets ind i. Til hvert tema er der nogle konkrete eksempler på, hvilke påstande der har floreret, samt hvad vi ved fra fx. sundhedsstyrelsen. Forhåbentlig vil dette bilag kunne guide dig i dit kommende annoterings-arbejde.

\section{Annoterings-ark}

Alle annotators har fået udleveret et personligt excel dokument med tweets de er ansvarlig for at kode. Eksempel herunder:

Hver linje/række i arket er et tweet som du skal give input til. Herunder er hver kolonne i excel arket forklaret: 
Kolonner der kræver dit input

- NAVN: Angiv dine initialer

- SCORE: Angiv om tweetet spreder misinformation, afstandtagen fra misinformation, osv.

Kolonner der kræver dit input afhængig af hvilken score du har givet et tweet

- HUMOR?: Angiv ja, hvis et tweet gør brug af humor

- SVAER?: Angiv ja, hvis det var svært at annotere tweetet

Kolonner du blot skal læse

- TEKST: Tweetets indhold

- TEMA: Det overordnede tema som tweetet passer ind $\mathrm{i}$

I det næste afsnit har vi beskrevet fremgangsmåden for at annotere hver tweet.

\section{Fremgangsmåde for annotering}

Din opgave, som annotator, går ud på at hjælpe os med at kategorisere vores datasæt, således, at vi for hvert tweet ved, om det spreder eller tager afstand fra misinformation. Derudover skal du for hvert tweet notere, hvorvidt det gør brug af humor og om det var svært at foretage kategoriseringen.

Du bedes følge nedenstående retningslinjer

- Det annoterings-ark du har fået udleveret knytter sig til det samme overordnede tema. Før du begynder at annotere, bedes du læse tema beskrivelsen og eksemplerne i vores bilag.

- Det er op til dig at vurdere, hvordan det enkelte tweet skal kategoriseres. Ved denne vurderingen skal du tage højde for det eksplicitte og implicitte indhold af hvert enkelt tweet.

- Det er vigtigt, at du giver alle tweet en score, også selvom du er i tvivl. I de tilfælde, hvor du kommer i tvivl, skal du indikere dette under sværhedsgraden.

- Hvis du giver et tweet scoren irrelevant, skal du springe kolonnerne humor eller svær over og gå videre til næste tweet.

\section{Beskrivelse af kategorierne}

Beskrivelserne i dette afsnit er inddelt efter hvilken kolonne du skal udfylde i annoteringsarket.

\subsection{Score}

I denne kolonne bedes du angive om du mener at tweetet:

- Spreder misinformation

- Afstandtagen fra misinformation

- Irrelevant

\section{Spreder misinformation}

Du skal notere, spreder misinformation, ved alle tweets, som fremsætter fejlagtige påstande som sande og hermed spreder misinformation. Det er afgørende, at afsenderen fremstår som enige i det fejlagtige budskab. Et eksempel på en misinformations tweet er: 
Eksempel 1:

Corona findes ikke! Det er en løgn, staten bruger til at $\varnothing$ ge kontrollen med befolkningen!

Vågn op!

\section{Eksempel 2:}

@tv2danmark corona blev udviklet af nsa til at infiltrere huawei 5g netværk

Eksempel 3:

har lige hørt at en af de kommuner der er hårdest ramt af corona, er helsingør $\oslash 0$

Figure 1. Eksempler på en misinformations tweets.

\section{Afstandtagen fra misinformation}

Du skal notere, tager afstand fra misinformation, ved tweets, der gør grin med misinformation eller personer, der tror på misinformationen. Tweets, der omtaler misinformation med en vis underliggende distance og tweets, der direkte modargumenterer misinformation. Tweets i denne kategori vil ofte indeholde en fejlagtig påstand, men fremstillingen af påstanden vil enten være distanceret, ironisk eller efterfulgt af et modargument. Det kræver således en grundig læsning af tweeten af identificere denne kategori.

Ironiske virkemidler: Vær særlig opmærksom på emojis, ironiske hashtags og ordsprog, samt citationstegn, da disse virkemidler kan ændre betydningen af et tweet (Se afsnit 4.2 om humor).

\section{Eksempel 4:}

Corona findes ikke! Det er en løgn, staten bruger til at $\varnothing g$ gentrollen med

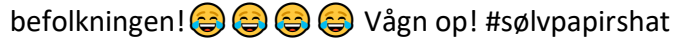

\section{Eksempel 5:}

@*** @*** så også en, der var overbevist om, at corona skyldtes, at kineserne

eksperimenterede med $5 \mathrm{~g}$ :-:

\section{Eksempel 6:}

selv under en epidemi kommer de største fupmagere frem. ifølge hejlesen skyldes sygdomme som kræft følelsesmæssige traumer. men ikke \#covid19 åbenbart. den skyldes 5g-stråling. selvfølgelig! $\odot$ \#dkpol \#sundpol

Figure 2. Eksempler på tweets, der ændrer betydning med ironiske virkemidler.

Negationer: Læs hver tweet grundigt, da enkelte negationer som nej og $\underline{i k k e}$ kan ændre betydningen af en tweet uden store ændringer i ordlyden. Det betyder, at tweets, som bekæmper misinformation, ofte minder meget om tweets, der falder under kategorien misinformation.

\section{Eksempel 7:}

Corona findes! Det er ikke en $\emptyset \mathrm{gn}$, staten bruger til at $\emptyset$ ge kontrollen med befolkningen!

Vågn op!

Eksempel 8:@***@*** det sker allerede. jeg stoppede en bekendt i at sprede en video om at $5 \mathrm{~g}$ netværket var årsagen til sygdom, og ikke \#covid19. jeg delte en khan academy video om årsag og korrelation med ham og et foredrag fra videnskabernes selskab med lone simonsen om pandemier. nu er det slettet

Figure 3. Eksempler på tweets, der ændrer betydning ved brug af negationer. 
Irrelevant

Du skal notere, irrelevant, ved tweets, som ikke falder under en af de tre kategorier. Det kan både være tweets, som blot relateret til den generelle samtale om Corona og tweets, der handler om noget helt irrelevant. Påstande, der er sensitive overfor tid, noteres som irrelevante. Dette drejer sig om påstande, hvis sandhedsværdi varierer over tid f.eks. være påstande omkring smittetrykket i Danmark.

Eksempel 9:

Så har jeg fået min sidste HPV-vaccinen

Eksempel 10:

Regeringen har er langsomme til at udbetale Iøn kompensations pakkerne! Det er for dårligt folk bliver tvunget til at dreje nøglen om på deres forretninger

Figure 4. Eksempler på irrelevante tweets.

\subsection{Humor?}

Har du noteret tweetet som et, der spreder misinformation eller tager afstand fra misinformation, skal du også tage stilling til om tweetet gør brug af humor. Har du noteret tweetet som irrelevant, skal du springe annotering af humor over.

I denne kolonne bedes angive et Ja i de tilfælde, hvor et tweet gør brug af hum $\varnothing$. Det afgørende er her, om tweetet gør brug af humor til at udtrykke det komiske eller morsomme i en situation. Det kan både være tweets, der bruger humor direkte til at gøre grin med noget, men også tweets, der benytter humor indirekte ved f.eks. ironiske eller sarkastiske virkemidler, hvor et positivt udtryk stilles overfor et negativt. Indirekte brug af humor kan ofte gøre betydningen af et tweets tvetydigt - her skal du være særlig opmærksom på brugen af emojis.

Eksempel 11: @*** jeg skal give jer mundbind også kan du få en bøde men nå alt kommer til alt er det jo politiet der bære den smitte som folk er så bange for - 웅

Eksempel 12: efter at ha mødt talrige mennesker fra en filmproduktion med mundbindet siddende under hagen, er jeg noget frem til, at det må ha en opstrammende/forebyggende effekt på dobbelthagen. \#hagebind \#covid19dk \#øreforstaden

Figure 5. Eksempler på tweets det benytter humor.

\subsection{Svær?}

Har du noteret tweetet som et, der spreder misinformation eller tager afstand fra misinformation, skal du også tage stilling til hvor svært tweetet var at annotere. Har du noteret tweetet som irrelevant, skal du springe annotering af svær over.

I denne kolonne bedes du skrive JA hvis tweetet var svært at annotere. Hvis det ikke var svært skal du ikke skrive noget. Dette skal give os indblik i, hvilke tweets, der giver anledning til tvivl.

\section{Bilag A: Eksempler på misonformation og information i den danske mundbinds debat}

Dette tema omhandler fejlagtige påstande om konsekvenserne ved at bære mundbind. Tweets, der spreder misinformation inden for dette tema vil, ofte indeholde påstande, om sundhedsskadelige konsekvenser ved at bære mundbind. Tweets, der taler om effekten af mundbind i forhold til beskyttelse mod smittespredning, bør betragtes som irrelevante, da Sundhedsstyrelsen i løbet af dataindsamlingen 
har skiftet sine anbefalinger på dette område. Der findes imidlertid tweets, som hævder, at mundbind $\emptyset$ ger risikoen for at blive smitte med corona, påstande som denne bør annoteres under kategorien spreder misinformation.

\section{Eksempler på valid information}

Sundhedsstyrelsen skriver: Mundbind kan være et supplement til forebyggelse af smitte, når det bruges korrekt og sammen med $\varnothing v$ rige smitteforebyggende anbefalinger. Hav altid håndsprit og et mundbind med, så du kan tage det på, hvis det bliver nødvendigt. Vær desuden opmærksom på steder, hvor der er indført krav om mundbind eller visir.

https://www.sst.dk/da/corona/Forebyg-smitte/Mundbind

\section{Eksempler på falske historier}

Påstand 1: Mundbind kan aktivere virus

I et interview siger tidligere virolog, Judy Mikovits, at man ligefrem risikerer at blive syg af at have mundbind på. At bære maske aktiverer din egen virus. Du bliver syg af din egen genaktiverede coronavirus, og hvis det tilfældigvis er SARS-CoV-2, så er det et stort problem, siger hun i videoen.

FALSK: Men også den idé afviser Jan Pravsgaard Christensen: Det er også pladder. Hvis man er smittet, er man smittet, og man kan ikke blive mere eller mindre smittet. Det kan være mere eller mindre alvorligt, men det skyldes ikke mundbind. Jeg vil nærmest æde min hat på, at det tager lige lang tid at komme sig over influenza eller covid-19 med eller uden mundbind, siger han.

Link: https://www.tjekdet.dk/faktatjek/det-er-noget-pladder-viral-video-med-falske-corona-paastandehitter-nu-ogsaa-i-danmark

Påstand 2: Der eksisterer en kræftrisiko ved at bære mundbind

Hvis du bærer mund bind eller andre former for masker, der blokerer for luftvejene, risikerer du at få kræft. Sådan står der i grove i træk i et facebookopslag, som er vist hos brugere på det sociale medie op mod 20.000 gange. Manden bag opslaget er Mads Palsvig, der er partiformand i JFK21, som ifølge partiets egen hjemmeside forsøger at blive opstillingsberettiget til næste folketingsvalg. Ifølge facebookopslaget er årsagen til kræftrisikoen tilsyneladende, at et lavt niveau af ilt i celler kan forårsage cancer. Og da mundbind minimerer menneskers iltoptag, er konklusionen lige for, mener Mads Palsvig.

FALSK: Men de forskere, TjekDet har talt med, køber ikke hans argumentation. De to ting, han nævner, er taget ud af sammenhæng. Der er intet belæg for, at mundbind skulle forårsage kræft, siger Johnni Hansen, der er seniorforsker hos Kræftens Bekæmpelse. Han bakkes op af Ursula Falkmer, der er klinisk professor og forskningsansvarlig overlæge på Aalborg Universitetshospitals kræftafdeling. Han (Mads Palsvig, red.) refererer til gode, veldokumenterede studier, men han tolker det noget mærkeligt, vurderer hun.

Link: https://www.tjekdet.dk/faktatjek/eksperter-affejer-partileders-paastand-om-kraeftrisiko-vedmundbind

Påstand 3: At bære mundbind kan føre til hyperkapni (for meget $\mathrm{CO} 2$ i blodet)

Mundbind kan give så meget $\mathrm{CO} 2 \mathrm{i}$ blodet, at man i værste fald kan d $\varnothing$ af det. Sådan lyder det i en pamflet fra det danske, politiske parti JFK21 - Jorden Frihed Kundskab. Pamfletten, der på den ene side bærer Sundhedsstyrelsens officielle logo, er de seneste dage blevet delt ud af repræsentanter fra partiet og 
online via partiets sociale medier. Angiveligt skulle mundbindene være farlige, fordi man med bind for munden ikke skulle være i stand til at ånde ordentligt ud. Det kan man få vand i lungerne af, hævder facebookopslag, mens der fra JFK21s side og gennem andre facebookopslaget blevet ytret, at mundbindene forårsager tilstanden hyperkapni, hvor man har for meget $\mathrm{CO} 2 \mathrm{i}$ blodet.

FALSK: Men påstandene har ikke noget på sig, fastslår forskere, TjekDet har talt med. Det er ikke muligt at få hyperkapni grundet mundbind. Man indånder ikke større mængder CO2, når man har mundbind på. Der er mere $\mathrm{CO} 2 \mathrm{i}$ udåndingsluften end i indåndingsluften, så det er kun, hvis man ikke kan komme af med sin udåndingsluft, at det kan begynde at hobe sig op. Desuden er de mundbind, man ofte bruger i forbindelse med COVID-19, de samme mundbind, som kirurger kan bruge i forbindelse med timelange operationer helt uden problemer, siger overlæge og forskningsleder på Klinisk Institut på Syddansk Universitet Christian B. Laursen. Ilten kan sagtens trænge ind og CO2en åndes frit ud gennem de mundbind, der anbefales mod covid-19, siger han.

Link: https://www.tjekdet.dk/faktatjek/pamflet-bruger-sundhedsstyrelsens-logo-til-sprede-usandhederom-mundbind-0

Påstand 4: Mundbind skader hjernen ved at begrænse mængden af indåndet ilt Man kan få permanente hjerneskader ved at bruge mundbind! I en video fortæller en kvinde, som giver sig ud for at være neurolog, at det at bære mundbind kan føre til mangel på ilt i blodet, hvilket kan skade hjernen - særligt hos børn og unge. Iltmanglen skulle ifølge videoen opstå, fordi mundbindet tvinger bæreren til at indånde den samme luft, som vedkommende netop har udåndet. Og det gør, at en stor mængde af kuldioxid - eller CO2 - indåndes.

FALSK: Men brug af mundbind påvirker ikke iltforsyningen til hjernen, skriver Correctiv - heller ikke hos børn og unge. Mundbindet ændrer ikke sammensætningen af den luft, vi indånder, siger en ekspert til faktatjekmediet, for luften kan sagtens passere gennem masken. Mundbind begrænser således ikke den ilt, man kan optage, når man har mundbindet på og skader derfor heller ikke hjernen.

Link: https://www.tjekdet.dk/faktatjek/seneste-faktatjek-om-coronavirussen

Påstand 5: Teflon i mundbind udgør en sundhedstrussel ved almindeligt brug

De blå engangsmundbind, mange bruger i disse tider, er sprøjtet med det syntetiske kemikalie teflon, og det kan give bæreren symptomer som feber, trykken for brystet, stakåndethed, hovedpine, hosten og ondt i halsen.

FALSK: Og det er faktisk rigtigt, at kemikaliet teflon bruges i produktionen af nogle engangs mundbind, skriver mediet. Oftest bruges dog en anden type af plastik ved navn polypropylen. Men skulle man få fingre i mundbind, der indeholder teflon, er der som udgangspunkt ingen grund til bekymring. Mundbind med teflon er nemlig ikke farlige ved helt almindeligt brug. Ifølge Full Fact er det først, når teflon varmes op til meget høje temperaturer - mellem 300 og 400 grader - at der er dokumentation for, at man kan opleve influenzalignende symptomer, som dem facebookopslaget beskriver.

Links: https://www.tjekdet.dk/faktatjek/seneste-faktatjek-om-coronavirussen \& https://fullfact.org/health/teflon-masks-symptoms/ 
Påstand 6: Mundbind var medskyldig i 50 millioner dødsfald under den spanske syge

For omtrent 100 år siden døde cirka 50 millioner mennesker under influenzapandemien den spanske syge. Men ifølge et billede, der florerer i opslag på sociale medier, var det ikke virussen, der var skyld i de mange $\mathrm{d} \emptyset \mathrm{dsfald}$. Det var derimod en bakteriel lungebetændelse. Den bakterielle lungebetændelse var forårsaget af.... vent på det, vent på det.... mundbind (masks, oversat til dansk), står der i opslaget, der gengiver et amerikansk blogindlæg skrevet af Anna von Reitz, en selvudnævnt internet-guru. I indlægget kan man læse, at sammenhængen mellem lungebetændelse, mundbind og det høje dødstal blev opdaget af en række amerikanske forskere i 2008, heriblandt top-epidemiologen Anthony Fauci, den amerikanske pendant til Søren Brostrøm, direktør for Sundhedsstyrelsen. Anthony Fauci ved altså, at brugen af mundbind under influenzapandemier kan føre til højere dødelighed, lyder anklagen. Alligevel anbefaler han at bruge mundbind under coronapandemien

FALSK: Men anklagen bygger på et falsk grundlag. Anthony Fauci var rigtignok en del af et forskerhold, der i 2008 opdagede, at årsagen til den høje dødelighed under den spanske syge var lungebetændelse forårsaget af en bakterie. Men det havde ikke det fjerneste at gøre med mundbind.

Link: https://www.tjekdet.dk/faktatjek/var-mundbind-medskyldig-i-50-millioner-doedsfald-under-denspanske-syge

Påstand 7: Bærere af mundbind bliver især smittet med ny coronavirus

Det er fortrinsvis folk, der går med mundbind, der bliver syge med covid-19. Sådan lyder det i både danske og amerikanske facebookopslag, der henviser til en undersøgelse fra den amerikanske sundhedsmyndighed Center for Disease Control and Prevention (CDC). Ifølge opslagene viser unders $\emptyset$ gelsen, at personer, der bruger mundbind, i højere grad bliver smittet med den ny coronavirus, end folk der ikke gør. Og derfor gør mundbindene angiveligt kun ondt værre

FALSK: Men både præsident Trump og de danske og amerikanske facebookbrugere har tolket undersøgelsen forkert. Den viser nemlig slet ikke, at mundbind $\emptyset$ ger risikoen for at blive smitte med ny coronavirus. I stedet når CDC frem til, at mundbind faktisk både skærmer mundbindsbæreren og forhindrer vedkommende $i$ at smitte andre.

Link: https://www.tjekdet.dk/faktatjek/nej-undersoegelse-viser-ikke-isaer-baerere-af-mundbind-bliversmittet-med-ny-coronavirus 


\section{Appendix E: Subcategories for the qualitative analysis}

\section{Qualitative coding subcategories}

Tweets spreading misinformation:

- Denying the pandemic: These tweets deny the existence of either the coronavirus pandemic or COVID-19 itself.

- Facemasks make one sick: These tweets express health-related concerns about the usage of facemasks.

- Blaming immigrants: These tweets blame immigrants and visible minorities for the spread of the coronavirus in Denmark.

Tweets rejecting misinformation:

- Criticizing newspapers: These tweets critique public news sources for their misleading portrayal of the coronavirus.

- Countering misinformation claims: These tweets present rebuttals or counterarguments to misinformation claims.

- Ridiculing spreaders: These tweets contain mocking terms about believers of misinformation but do not address the believers. 